S9 EQUIVALENCE OF FLUTICASONE PROPIONATE/ SALMETEROL DELIVERED VIA AIRFLUSAL ${ }^{\circledR}$ FORSPIRO $^{\circledR}$ AND SERETIDE ${ }^{\circledR}$ ACCUHALER $^{\circledR}$ IN ADOLESCENT AND ADULT ASTHMA

${ }^{1} \mathrm{P}$ Kuna, ${ }^{2} \mathrm{G}$ Gath, ${ }^{2} \mathrm{U}$ Thyroff-Friesinger, ${ }^{3} \mathrm{~S}$ Jones. 'Medical University of Lodz, Lodz, Poland; ${ }^{2}$ Hexal AG, Holzkirchen, Germany; ${ }^{3}$ Sandoz International GmbH, Holzkirchen, Germany

\subsection{6/thoraxjnl-2015-207770.15}

Introduction and objectives Guideline-defined asthma control may be achieved and maintained in the majority of patients by treatment with a combination of a corticosteroid and a long-acting $\beta_{2}$-agonist. AirFluSal ${ }^{\circledR}$ Forspiro $^{\circledR}$, a multi-dose dry powder inhaler (mDPI), provides this proven combination of inhaled corticosteroid fluticasone propionate (FP) and a long-acting inhaled $\beta_{2}$-agonist salmeterol (Sal). This study compared the efficacy of AirFluSal ${ }^{\circledR}$ Forspiro ${ }^{\circledR}$ with Seretide ${ }^{\circledR}$ Accuhaler $^{\circledR}$ in adolescent and adult patients with moderate-to-severe persistent asthma.

Methods This study, conducted in 279 patients (12-65 years) with GINA guideline-defined moderate-to-severe persistent asthma, was undertaken as a double-blind, double-dummy, parallel-group, multicentre trial. Patients were randomised to 12 weeks treatment with AirFluSal ${ }^{\circledR}$ Forspiro ${ }^{\circledR} 500 \mu \mathrm{g} / 50 \mu \mathrm{g}$, or Seretide ${ }^{\circledR}$ Accuhaler ${ }^{\circledR}$ $500 \mu \mathrm{g} / 50 \mu \mathrm{g}$. Primary efficacy measures were the change from baseline of the forced expiratory volume in $1 \mathrm{~s}\left(\mathrm{FEV}_{1}\right)$ to show non-inferiority of AirFluSal ${ }^{\circledR}$ Forspiro ${ }^{\circledR}$ to Seretide ${ }^{\circledR}$ Accuhaler ${ }^{\circledR}$ (non-inferiority margin $\Delta=-0.200 \mathrm{~L}$ ) and the area under the $\mathrm{FEV}_{1}$ curve at study termination $\left(\mathrm{AUC}_{0-12}\right)$. Secondary endpoints included mean changes in $\mathrm{FEV}_{1}, \mathrm{FEV}_{1} \%$ predicted, morning peak expiratory flow (PEF) and global evaluation of efficacy. Safety was assessed and patient preference for each device was rated using a visual analogue scale (VAS).

Results Assessment of the effect of treatment on the absolute change in $\mathrm{FEV}_{1}$ from baseline to study termination demonstrated non-inferiority between AirFluSal ${ }^{\circledR}$ Forspiro ${ }^{\circledR}$ and Seretide ${ }^{\circledR}$ Accuhaler ${ }^{\circledR}$ (difference in least squares mean $[95 \% \mathrm{CI}]=-0.032$ $\mathrm{L}[-0.121 ; 0.057])$. Assessment of $\mathrm{AUC}_{0-12}$ at study termination demonstrated equivalence between devices. All secondary efficacy measures demonstrated comparable results for both inhalers, with no significant differences observed. The use of rescue medication and the average asthma symptom scores decreased from baseline in a similar manner for both devices. Overall safety profiles were equivalent. Patient ratings for each device were $81.97 \pm 13.89 \mathrm{~mm}$ VAS for AirFluSal ${ }^{\circledR}$ Forspiro $^{\circledR}$ and $79.67 \pm 16.48 \mathrm{~mm}$ VAS for Seretide ${ }^{\circledR}$ Accuhaler $^{\circledR}$ (data includes 276 patients randomised at baseline to use the devices at a dose of $100 \mu \mathrm{g} / 50 \mu \mathrm{g}$ ).

Conclusions AirFluSal ${ }^{\circledR}$ Forspiro ${ }^{\circledR}$ shows therapeutic equivalence to Seretide ${ }^{\circledR}$ Accuhaler ${ }^{\circledR}$, providing a proven combination treatment in an intuitive, easy-to-use device.

\section{S10 THE IMPACT OF OMALIZUMAB ON LUNG FUNCTION AND QUALITY OF LIFE IN PATIENTS WITH SEVERE ALLERGIC ASTHMA IN UK CLINICAL PRACTICE: A MULTI-CENTRE PROSPECTIVE OBSERVATIONAL STUDY - APEX II}

${ }^{1} \mathrm{R}$ Niven, ${ }^{2} \mathrm{R}$ Kurukulaaratchy, ${ }^{3} \mathrm{~L}$ Heaney. ${ }^{1}$ Academic Health Science Centre, University of Manchester, Manchester, UK; ${ }^{2}$ Southampton General Hospital, Southampton, UK; ${ }^{3}$ Belfast City Hospital, Belfast, UK

\subsection{6/thoraxjnl-2015-207770.16}

Background A previous retrospective UK study (APEX I) demonstrated omalizumab significantly reduced oral corticosteroid (OCS) use, exacerbations, lung function and quality of life (QoL in severe allergic asthmatic (SAA) patients.

Aim This multi-centre observational study was conducted to confirm the observed retrospective findings prospectively.

Methods Retrospective data were collected 12 months prior to and prospective data were collected 12 months following omalizumab initiation in SAA patients $\geq 16$ years. The primary endpoint was the change in mean daily oral corticosteroid (OCS) dosage. Secondary endpoints included changes in lung function, ACT and AQLQ scores and missed days in education/work and

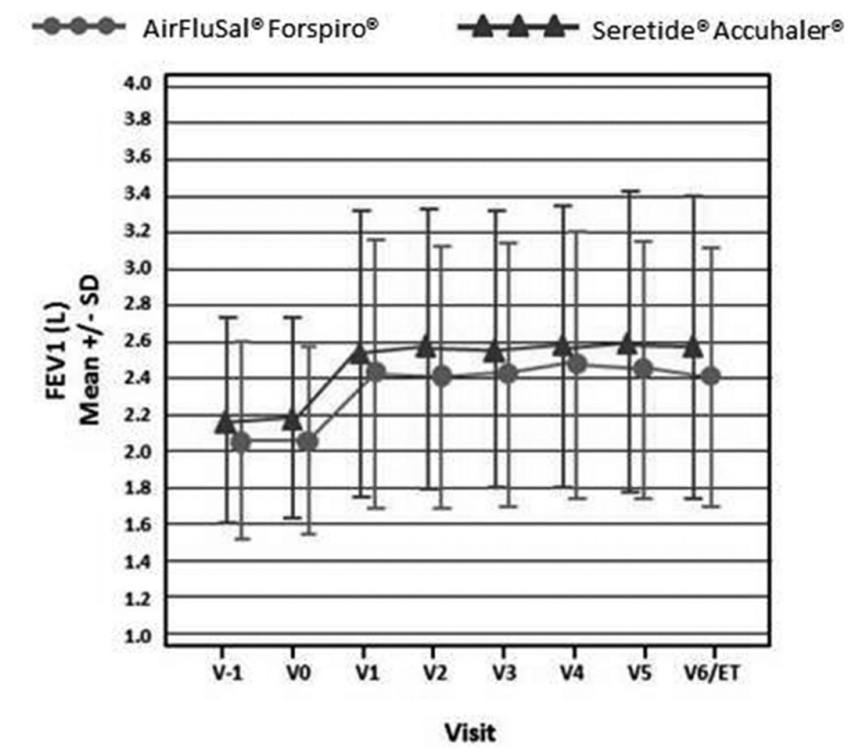

Baseline is defined as mean of 2 pre-inhalation values at randomization visit (week 0 ).

Abstract S9 Figure 1 Effect of treatment on baseline* FEV $_{1}$ by inhalation with AirFluSal ${ }^{\circledR}$ Forpiro $^{\circledR} 500 \mu \mathrm{g} / 50 \mu \mathrm{g}$ or Seretide ${ }^{\circledR} 500$ Accuhaler $^{\circledR}$ 